Competition, innovation and racing for priority at the U.S. Patent and Trademark Office

\author{
Linda R. Cohen and Jun Ishii
}

August 31, 2005

\begin{abstract}
:
The U.S. Patent and Trademark Office resolves patent priority disputes in patent interference cases. Using a random sample of cases declared between 1988 and 1994, we establish a connection between patent interferences and patent races, and then use the data to consider some key issues in dynamic competition and innovation. We look at the incidence and distribution of patent races by technology, evidence for strategic delay of innovation by incumbent firms, and evidence that patent races moderate incentives to delay. Our results have implications for patent policy in general and for evaluating the U.S. "first to invent" patent priority rule.
\end{abstract}

Keywords: patent race; patent interference; US Board of Patent Appeals and Interferences; patent litigation; innovation; research and development.

JEL Codes: K41, L20, O31, O34. 


\title{
Competition, innovation and racing for priority at the U.S. Patent and Trademark Office
}

\author{
Linda R. Cohen and Jun Ishii*
}

August 31, 2005

\section{Introduction}

A substantial theoretical literature investigates how competition for a patent affects dynamic competition, the level of investment in research and the rate of innovation. Under some circumstances, competition - a patent race - efficiently enhances investments in research; in others it (in theory) leads to excessive expenditures on invention, preemptive patenting, and delayed innovation. The lack of suitable data on patent races has hindered an evaluation of either the importance or the consequences of actual patent races. ${ }^{1}$

This paper explores a rich source of information on patent races: U.S. patent interference cases. Patent interferences are the means by which the U. S. Patent and Trademark Office (USPTO) resolves priority disputes between patent applicants. The disputes center around the discrepancy between the date at which each litigant purportedly invented the technology and the date at which he filed for patent protection. The cases thus provide a window into the decisions of firms about the timing of research

\footnotetext{
* Department of Economics, UC Irvine. Cohen thanks the UCI Center for the Study of Democracy for financial support and Resources for the Future for both its financial support and hospitality during the initial stages of this study. Steven Nguyen and Rachel Smith provided excellent research assistance. We thank David Brownstone, Amihai Glazer, William Kingston, Josh Lerner, David Miller and seminar participants at the 2005 IIOC, the UCLA Innovation Workshop, and UCI. We are deeply indebted to the staff of the PTO File Information Unit for accommodating our hundreds of requests for files All opinions,

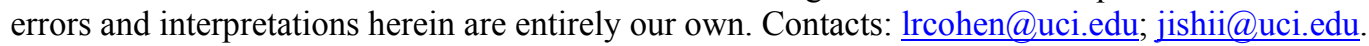

1 There are very few empirical studies of patent racing per se. The topic was taken up by Cockburn and Henderson (1995) in a case study of the ethical drug industry, who find no support for "winner-take-all" patent races.
} 
and innovation and about the impact of patent policies on those decisions.

In this paper, we find support for the classic Arrovian hypothesis that incumbents delay the introduction of innovations relative to challenger firms. ${ }^{2}$ We derive an empirical model to test strategic filing behavior and show that while incumbents would prefer to delay introduction of innovations, they respond to competitors' patent filings by accelerating the filing of their own patent applications. In other words, a patent race leads to racing, in this case mitigating the incentive of incumbents to delay innovation.

The tests rest on identifying interferences with patent races, and hence the actions of litigants with strategic choices to obtain or lock up patent rights. The first part of this paper presents data on the distribution of interferences across technology categories to argue that the cases are consistent with strategic racing but not with (or not exclusively with) alternative reasons for why an interference might arise. Consistent with theoretical studies of patent races, the incidence of interferences is concentrated in technology categories where patent rights are generally thought of as strong, such as chemicals and drugs, and is very low in electronic and computer categories. It differs in significant ways from the incidence of patent infringement litigation, which suggests that the observed pattern of interferences reflects broader industry research duplication rates rather than the non-representative preferences of particular parties for litigation.

This study also provides some information about the institution of U.S. patent interference. Patent interferences exist to support the unique American first-to-invent patent standard. All other countries award patents to the inventor who first files for a patent on the invention. This has led to calls for the U.S. to change its priority standard

\footnotetext{
2 Arrow (1962), Reinganum (1982). Our results add support to the case studies and surveys that also provide empirical support for the incentives of incumbents to delay. See Lerner (1997), Czarnitzki and Kraft (2004).
} 
in the interest of further patent harmonization with other countries, ${ }^{3}$ and has renewed interest in the value of the interference process. ${ }^{4}$

We find that the impact of the priority standard on patent activity is not benign. While interference cases are rare - only 1400 were declared between 1988 and 1994 their incidence among strong-patent technologies is nearly as high as, and in the case of biotechnology patents, higher than estimates of infringement rates. ${ }^{5}$ Furthermore, the assignment of rights under the first-to-invent and first-to-file rules are more likely to differ for less derivative patents, arguably the patents of greatest interest to innovation policy. At the same time, we find little evidence that the interference procedure benefits the small firms who have traditionally been served up as the main course in defense of the priority standard. Indeed, most of the firms that participate in patent interference cases are very large, consistent with the expectation that patent races are the province of corporate research laboratories with well-defined goals and good information about the activities of the competition. Finally, and perhaps most troubling, our evidence suggests that the first-to-invent policy undermines potentially desirable aspects of patent races, and thus may have an impact on innovation well beyond the firms that wind up in formal interference litigation. $^{6}$

The paper proceeds as follows. The next section introduces the patent interference process, provides some details about when and how the process can be used

\footnotetext{
${ }^{3}$ Representative Lamar Smith introduced legislation in Congress on June 8, 2005 that (among sweeping reforms) proposes changing the U.S. system to a first-to-file standard. See the News Release on Congressman Lamar's web site, at http://lamarsmith.house.gov/news.asp?FormMode=Detail\&ID=648.

${ }^{4}$ Lemley and Chien (2003), Mossinghoff (2002). Another recent study of interferences that raises some of the issues addressed here is Kingston (2004).

5 The incidence of interferences appears to have dropped in the late 1990s, but due to the long lag in the distribution of cases, we cannot speculate in an informed manner on whether the change in interference patterns in significant.

${ }^{6}$ Our conclusions are anticipated by Gholtz (2000).
} 
and presents summary statistics about interferences. Section 3 discusses the rates of interfering in different technology categories and discusses our strategy for identifying interferences as patent races. We then relate the actions of litigants and outcomes in interference cases to the incumbency-challenger debate. Section 4 contains an empirical model of strategic filing, section 5 discusses the independent variables, and section 6 contains regression results. Section 7 returns to patent interference policy issues, and concludes.

\section{Interference Cases at the US Board of Patent Appeals and Interferences}

U.S. patent priority rules are currently based on the principle that the first person who invents a patentable invention should receive the patent. When two or more parties claim to satisfy that standard, a patent examiner can declare an interference proceeding to determine priority. ${ }^{7}$ Interference cases and rules are remarkably complex, and we discuss here only general issues that affect the way that we formulate our hypotheses and interpret our results. ${ }^{8}$

\subsection{Declaring an interference.}

An interference declaration has two main components. First, the patent examiner identifies one of the parties as the senior party and the other party (or parties) as the junior party (junior parties). Each party is awarded a "benefit date," which is a starting point for the determination of priority. The senior party has the earliest benefit date. The other key piece of the interference declaration is the "count" (or counts) which state

\footnotetext{
7 Formally, the Commissioner of Patents declares the interference but the examiners appear to call the shots.

8 See Kingston (2004) for an overview of Patent Interference practices, and Lipscomb (1986) for details, including a history.
} 
precisely what technology is in dispute. The declaration also identifies which claims in the patents or patent applications of the parties correspond to the interference count. The senior party starts out with a presumption of priority, and the junior party has the burden of proof to show that he invented first.

The PTO issues a final decision or judgment in all cases, which states the resolution of the disputed technology. In about a quarter of the cases, the Board of Patent Appeals holds a final hearing presided over by administrative judges. ${ }^{9}$ The remaining cases settle before a hearing, usually when one party relinquishes his claim by requesting an adverse judgment, at which point the remaining party is awarded priority and can either seek or retain the patent. The cases that settle typically do so after a patent examiner has issued some preliminary findings, and also after the parties agree to additional, confidential settlement terms that may involve licensing the technology or sharing other technology. Interferences declared between 1988 and 1994 concluded in an average of 623 days, with a minimum time of sixteen days and a maximum of over ten years. $^{10}$

\subsection{Types of Interferences}

Unlike infringement cases, private parties cannot sue for interference. However, they can alert patent examiners to a potential interference, and request that one be declared. Knowledge of a potential interference arises in three circumstances which define the three distinct types of interferences. Patent examiners identify an interference

\footnotetext{
9 The cases are simpler - and much cheaper - than infringement suits. A key difference is in the rules of discovery which is very limited in the interference setting. See Gholtz (2001) for a comparison of the interference and infringement cases. Like all administrative decisions, BPAI decisions can be appealed to the federal courts.

${ }^{10}$ These statistics are based on our sample, described below. No comparable statistics for the population of interferences exist, but these numbers, and the other characteristics described here, are very close to those published by Calvert and Sofocleous $(1989 ; 1992 ; 1995)$ for the population of patents distributed in the late 1980 s and early 1990 s.
} 
when it involves two applications ("applicant only"). Applications are sent to examiners at the PTO who specialize by technology so that two interfering applications would most likely be examined by the same examiner, and certainly in the same group. Second, the junior party may identify, and request, an interference when the senior party has a recently issued patent, and the junior party has an application pending before the PTO ("senior party patentee"). Both applicant-only and senior-party-patentee cases are called interferences "for" the junior party, as they provide an opportunity for the junior party to claim rights that would otherwise be assigned to the senior party.

The third and most common form of interference is when the senior party requests one based on the recently-issued patent of the junior party (“junior party patentee"). ${ }^{11}$ Here, the senior party usually files his application after the junior party, but obtains filing priority by having either a foreign patent or a parent patent. Thus the benefit date for the senior party corresponds to the application filing date for a different patent that incorporates the technology that corresponds to the interference count. This form of interference is considered an interference "for" the senior party, who has an opportunity to dispute a patent awarded to the junior party. Table 1 gives the incidence of each of these forms of interference and the basis for the benefit dates awarded to the junior and senior parties.

\subsection{Interference Outcomes}

Whether the interference is resolved by settlement or the BPAI, the result is one of four outcomes. The subject matter can be awarded to the senior party or to one of the junior parties. These are the possible "priority outcomes" for the case, and are the focus

\footnotetext{
${ }^{11}$ Interferences where both parties have patents are rare, but also possible. They are litigated by federal district courts rather than the PTO.
} 
of sections 4,5 and 6 .

A third possibility is that the examiner or the BPAI will decide that the claims of the parties do not correspond to the count, and that their applications are in fact for separate inventions. These cases are coded as both parties winning. ${ }^{12}$ Finally, since 1984 the BPAI has made patent validity determinations in the course of an interference. ${ }^{13}$ In some cases, it rules that neither party can patent the technology. We code this as "both lose". ${ }^{14}$ Generally one party will lose on priority grounds, and the other on one of the standard reasons for patent invalidity such as prior art or failure to disclose best practice in the application. ${ }^{15}$ Table 2 shows the distribution of outcomes.

\subsection{Characteristics of interferences: sample statistics}

Our sample is composed of 668 interferences that involve 1424 applicants. ${ }^{16}$ The cases correspond to a $50 \%$ random sample of the interference numbers assigned to cases declared between 1988 and 1994. Tables 3 - 7 provide some information about characteristics of the interference cases. Interference parties are heavily weighted towards domestic corporate inventors relative to all applicants for U.S. patents. The shares reflect Kingston's (2004) observation that interferences are more likely to arise in corporate research settings, as corporations would be more likely to set similar goals - in brief, to enter a well-identified patent race. The same observation appears to apply to university research. While the cell sizes are modest, our sample has a healthy

\footnotetext{
${ }^{12}$ This category includes cases ruled to have "no interference in fact" and those with split awards where it appears as if neither party's split includes the lion's share of value.

1335 USCS sec. 135(a), PL 98-622 sec. 202, 98 Stat 3386 (1984).

${ }^{14}$ A fairly common progression in these cases is that the party who anticipates losing on priority will try to claim no-interference-in-fact; if that is unsuccessful, he will introduce evidence challenging the validity of the other party's application or patent. Thus issues of both patent scope and patent validity are common grist for patent interference cases. This raises the fascinating question of whether the patent interferencetype institution could substitute for that of a federal district court.

${ }_{15}$ Material in an interference count is supposed to be patentable. See Lipscomb (1986), p. 342, 343.

${ }^{16}$ See the data appendix for sources and our sampling methodology.
} 
representation of university applicants: over four percent compared to $1.4 \%$ in the population of patents at that time.

Even restricting the comparison to corporate patentees, those involved in interference cases are much larger, from a patenting standpoint, than the typical patenting corporation. Tables 4 and 5 present comparison data calculated from the NBER database. ${ }^{17}$ Using any standard - mean portfolio, $75^{\text {th }}, 90^{\text {th }}, 95^{\text {th }}$ percentile, controlling for technology class - our sample assignees are huge.

The research activities of junior and senior parties are largely commensurate for our sample. (see Tables 6 and 7) Overall, junior parties are somewhat larger than the senior parties, and while the difference is statistically significant, it does not hold across technology categories.

\section{Patent Races and Interference Rates}

A primary concern for this study is that the interference data are representative of patent races. While some such races presumably do result in an interference, others would not: interferences are only declared when the parties file in close proximity and when each can make an argument for invention priority. Races where one party recognizes his probable defeat and abandons the project would not end in an interference. Thus our sample can represent only the subset of races where researchers pursue the invention to its conclusion, and where the race has a photo-finish perspective.

A second problem is that interferences may arise for other reasons. Inventors may

\footnotetext{
${ }^{17}$ For Tables 4 and 5, we matched 624 of the corporate assignees in our sample with the NBER code, and based the comparative portfolio statistics on NBER's calculations for these assignees and for the NBER population.
} 
duplicate research projects through random selection of an invention topic. Firms may undertake a frivolous interference to hold up a competitor in litigation. While we cannot rule out either of these options on the basis of our data, the distribution of interferences across technology categories provides strong support that patent racing is an important aspect of interfering claims.

The classic patent races involve a group of firms intent on inventing the same well-defined product. Because the patent system decrees that the first firm to invent receives at least a disproportionate share of the invention reward, and because each firm's investment decreases the likelihood that other firms will be first, the firms impose negative externalities on each other. More firms will be looking for the same product, invention will be faster, and aggregate research expenditures will be greater than is jointly optimal for the firms. When firms strategize by taking into account the research plans of competitors, a contest, or strategic patent race ensues.

Reinganum (1982; 1989) emphasizes the role of appropriability in how races proceed. The ratio of "leader" to "follower" benefits defines the extent to which an inventor can appropriate the social value of his patent, or, in this context, the strength of a patent. When patents are strong, an increase in the number of firms increases per firm investment. When patents are weak the reverse relationship holds. Putting the results together, we expect to find too many firms in all innovative industries with unrestricted entry and valuable patent opportunities. ${ }^{18}$ But if strategic racing is at play, interferences will be concentrated in industries with strong patent rights (drugs, chemical formulae), as such industries are predicted to have greater per-firm spending and hence a higher

\footnotetext{
${ }^{18}$ Note that "too many" is relative to a coordinated profit-maximizing effort by the firms, not social welfare.
} 
likelihood of multiple invention within a short enough period of time to trigger an interference than are industries with weak patents (electronics, computers). ${ }^{19}$

Using the interference process for strategic litigation has different implications for the distribution of cases. Certainly a spurious interference has potential value. It may impose litigation costs and delay issuance of a patent to a competitor. To avoid the delay and costs, the meritorious litigant might settle with the interferer, and agree to attractive licensing terms, technology sharing, or other fruits of extortion common to infringement settlements. This process appears harder to abuse as interferences are declared by patent examiners, but, as is discussed above, litigants have a role in identifying potential cases. ${ }^{20}$ Infringement rates are a proxy for this kind of behavior. Lanjouw and Schankerman (2004) find a strong correlation between the probability that a patent is involved in infringement litigation and the characteristics of both the patent technology and the patent owners that make litigation attractive or unavoidable, including ease of settlement, litigation know-how and the benefits of tying up competitors in litigation. These features carry over directly to the interference milieu.

As with infringement, legal confusion or unsettled law could also give rise to interference cases. When it is unclear whether two parties have filed for separate or interfering patents, an examiner can declare an interference to settle the extent of each parties' claims. If this explanation is correct, the computer software and biotechnology categories will be over-represented in interferences. Finally, random duplication of research activities, randomly resulting in duplicate patent applications, suggests that the

\footnotetext{
19 There is remarkable agreement among empirical economists about the technologies characterized by strong versus weak patents. See Cohen et al (1997) and Schankerman (1998).

${ }^{20}$ An administrative proceeding may have a number of advantages over civil suits, including its greater apparent resistance to abuse by participants. See Jaffe and Lerner (2004), Hall et al., (2003), Kingston (2000). For a more skeptical view, see Lemley (2001).
} 
distribution of interferences would approximate the distribution for all patent applications.

Calculating the rate of interference from our data requires dealing with a truncation problem complicated by two issues: first, the rapid growth in the number of applications filed at the USPTO during the 1980s and early 1990s, and second, the concurrent changes in the shares of applications accounted for by each of the different technology categories. The appendix describes a methodology for dealing with truncation.

The results are summarized in tables 8 and 9 (see Appendix Table 1 for details). The likelihood that an application is involved in an interference in this period is from half to one-third the magnitude that it will be involved in infringement litigation. In the chemical and drug technologies, the likelihood is roughly equivalent or slightly higher, while in biotechnology we estimate the interference rate at twice the infringement rate: $5 \%$ of biotechnology applications enter into interference. If, as is argued earlier, interference represents the tip of a patent race iceberg, these estimates imply that a substantial number of patent races - and possibly substantial duplication of research effort - occurs in the biomedical and biotechnology fields.

We easily reject the hypothesis that the rates are equal in the different technology categories. The estimates of interference rates closely correlate to both estimates and conventional wisdom about when patents provide strong protection for intellectual property. The interference rate for chemicals is 1.46 times greater than the average and drugs are interfered at over three times the average. Computers and electrical patents are interfered at only half the average rate. Breaking the drug category into smaller 
technology subcategories shows that, while the rates are high in all of the subcategories, they are highest for inventions that correspond to chemical formulae, and lower for medical equipment.

The final two columns in tables 8 and 9 present estimates from two sources of the rate at which patents are involved in infringement litigation before the federal district courts. The estimate that incorporates data from the 1990s (second column) is nearly twice that of the first column, but both give very similar relative rates.

The rates for drugs and for the drug categories are among the higher relative rates for both types of patent litigation. But the similarity stops there. Interference rates are high for chemicals, while in infringement suits, chemicals patents are litigated at only half the average rate. Alternatively, the computer and electrical rates are the lowest for all interferences, at about half the average rate, while the estimates for infringement place computer rates at well above average and electrical rates at 80 to 90 percent of the average. Within the drug category, interference rates are high for actual chemical compositions - biotechnology drugs and other drugs -- and lower for medical equipment (although it is still nearly twice the average). On the infringement side, medical equipment has the highest litigation rate, with biotechnology and other drugs closer to average.

Results are mixed for the unsettled law hypothesis: the interference rate for biotechnology is very high, while that for computers is the lowest of all of the technology categories. Taken together these rates raise an interesting possibility. While unsettled law alone may not be able to drive priority litigation, it might at least contribute in that examiners declare interferences or parties request them in a greater fraction of potential 
cases. Supporting this view is the high rate of non-priority determinations in both biotechnology and computers (see Table 2). However, we caution against viewing these numbers as more than intriguing trends, as the cell sizes are small.

Overall, the table supports our identification strategy. Interference rates are far from uniform across technology categories. High interference rates are found in technologies with strong effective patent rights; low interference rates characterize the industries with weak effective patent rights. Abusive litigation does not appear to drive the interference rates. Finally, our estimates suggest that unsettled law may play a role in interferences, but more extensive data are necessary to determine how important the phenomenon may be.

\section{Dynamic competition: an empirical model of strategic filing}

If interferences are representative of patent races, then we can use their outcomes to investigate the nature and consequences of competition for patents. We consider here two issues related to innovation: first, that incumbent firms prefer to delay the introduction of new products relative to challengers, and second, that competition for a patent overcomes part of the incumbency delay.

A key hypothesis that emerges from the theoretical literature on innovation is that incumbents might prefer to delay introducing a new good relative to challengers because the new good cannibalizes revenue from their current product. A marketing delay should mean a delay in filing for a patent for three reasons: first, the patenting expenses are delayed until the firm is ready to market its invention. Second, delaying filing and patent issuance deprives competitors of the information that an application divulges about 
the invention. Finally, the limited patent term is scheduled when most valuable: when the product is actually sold rather than in part when the product is being readied for sale.

Delaying a patent until the firm is ready to market is an attractive strategy for any firm. However, the attraction varies by firm. Small firms, particularly start-ups, rely on their patent portfolio for financing. In cases where development and marketing are undertaken by entities other than the inventor, patents are critical to commercialization. Universities, startups and government agencies are less likely to employ a filing-delay strategy than are large corporations. Thus, while filing delays are not restricted to incumbent firms, the "Arrow" hypothesis predicts that, ceteris paribus, they will delay more because their target marketing date is later than for challenger firms.

If a competitor files for a patent in the interim the delaying firm is in trouble. The U.S. patent system, with its first-to-invent priority structure, is gentle to procrastinators, since a firm can file in response to the filing of a competitor and still obtain the patent. However, junior parties in interference cases are at a formal disadvantage: they carry the burden of proof to establish an early invention date and need to show diligence in reducing the invention to practice. ${ }^{21}$ Furthermore, if junior parties first file for a patent after the senior party has not only filed but been granted a patent, then the standard of proof on the junior party rises from a preponderance of evidence to the more stringent beyond reasonable doubt. Finally, if the junior party delays filing beyond a year from the issue date of the senior party's patent, technically he loses the option of entering an interference. Thus, potential penalties to tardy filing exist in law, even in a first-to-invent patent system.

To investigate strategic delay and strategic acceleration, consider the following

\footnotetext{
${ }^{21}$ See Lipscomb, p. 363.
} 
stylized model of the patent filing and BPAI ruling process. Suppose at most one of the two firms in interference is an incumbent. ${ }^{22}$ Denote the incumbent and challenger by subscripts $I$ and $C$ respectively, $i$ and $c$ are their respective invention dates, $T_{I}$ and $T_{C}$ are the earliest dates at which $I$ and $C$ could file their patent applications, $t_{I} *$ and $t_{C} *$ are the "ideal" dates subsequent to the earliest date at which they would file if they faced no competition from each other, and $t_{C}$ and $t_{I}$ are the dates that they actually file.

$$
\text { (4.1) } \begin{aligned}
T_{C} & =c+X 1_{C} \gamma 1+Z 1 \omega 1 \\
T_{I} & =i+X 1_{I} \gamma 1+Z 1 \omega 1
\end{aligned}
$$

$X 1$ are the characteristics that vary across inventors that affect the filing process.

$Z 1$ are the characteristics that affect the filing process that may vary across technologies but not across inventors working on the same technology. As interference cases depend on the difference in the timing, $T_{C}-T_{I}$, and not the absolute timing $\left(T_{C}, T_{I}\right), Z 1$ have no impact on our analysis.

Assume that challengers receive no challenger-specific benefit from delayed filing and thus file as soon as they can, so that $t_{C}=t_{C} *=T_{C}$. An incumbent, alternatively, would prefer to delay and file subsequent to the earliest date:

$$
t_{I}^{*}=T_{I}+\gamma^{*} I n c_{I}=i+X 1_{I} \gamma 1+Z 1 \omega 1+\gamma^{*} I n c_{I} \geq T_{I}
$$

where $\gamma^{*}$ is the desired delay due to incumbency incentives and $I n c_{I}$ measures the extent to which the firm is an incumbent.

If the incumbent firm files subsequent to the challenger, he incurs the

\footnotetext{
${ }^{22}$ The data allow a definition of incumbency that identifies at most one of the parties, so the model is consistent with data constraints, as well as presenting a strategic scenario simple enough to allow empirical investigation. We test for strategic behavior only when the litigants exemplify a limited set of characteristics; if such behavior obtains (as it surely does) to other pairs, our results will be weaker, but not obviously biased. Other simplifying assumptions discussed below are: (1) challengers obtain no benefits from delayed filing and (2) incumbents display a specific form of myopia in their actions.
} 
disadvantage of litigating from the junior party position. He thus may choose to reduce or eliminate the optional delay. Let $t$ be the time at which the incumbent files his application, and let his utility from filing at time $t$ be given by a quadratic loss function ${ }^{23}$ :

(4.3) $U(t)=\left[\begin{array}{c}-\theta\left(t-t_{I} *\right)^{2}-(1-\theta)\left(t-t_{C}\right)^{2} \text { if the incumbent is the junior party } \\ \text { where } 0<\theta \leq 1 \\ -\left(t-t_{I} *\right)^{2} \text { if the incumbent is the senior party }\end{array}\right.$

In the appendix we prove the existence of unique equilibrium strategies where challengers always set:

(4.4) $t_{C}=t_{C} *=T_{C}=c+X 1_{C} \gamma 1+Z 1 \omega 1$

or: $\quad c=t_{C}-X 1_{C} \gamma 1-Z 1 \omega 1$

and the incumbent sets:

$$
t_{I}=t_{I}^{*}=T_{I}+\operatorname{Inc} c_{I} \gamma^{*}=i+X 1_{I} \gamma 1+Z 1 \omega 1+I n c_{I} \gamma^{*} \text { if } t_{I}^{*}<t_{C}
$$

$$
t_{I}=\theta t_{I}^{*}+(1-\theta) t_{C} \quad \text { if } t_{I}^{*} \geq t_{C}
$$

To simplify the notation, we let $I n c_{I}$ be a component of $X 1$ which takes the value 0 when the party is not an incumbent. This does not affect our analysis as $I n c_{I}=0$ for challengers, leaving $X 1$ as before for those firms. Rewriting (4.6),

$$
\begin{aligned}
& t_{I}^{*}=(1 / \theta) t_{I}-((1-\theta) / \theta) t_{C}=i+X 1_{I} \gamma 1+Z 1 \omega 1 \\
& i=(1 / \theta) t_{I}-((1-\theta) / \theta) t_{C}-X 1_{I} \gamma 1-Z 1 \omega 1
\end{aligned}
$$

A case can have two challengers, both of whom follow the strategy in (4.4), a junior party-challenger and senior party-incumbent, who follow strategies $(4.4 ; 4.5)$ or a senior party-challenger and junior party-incumbent, who follow strategies $(4.4 ; 4.7)$. To simplify the notation, let $A$ denote the senior party and $B$ the junior party; $a$ and $b$ their

\footnotetext{
${ }^{23}$ This formulation incorporates a "myopia" assumption that the senior party-incumbent ignores the fact that if he files earlier he would increase the disadvantage to subsequent junior party-challengers.
} 
invention dates, and $f$ and $g$ their filing dates.

The BPAI assigns legal invention dates $\alpha$ and $\beta$ to $A$ and $B$ which are based on admissible evidence and possibly other factors. ${ }^{24}$ We model the BPAI ruling around the actual invention dates $(a, b)$ but allow for possible systematic and idiosyncratic deviation.

$$
\begin{aligned}
& \alpha=a+X 2_{A} \gamma 2+Z 2 \omega 2+\varepsilon_{A} \\
& \beta=b+X 2_{B} \gamma 2+Z 2 \omega 2+\varepsilon_{B}
\end{aligned}
$$

Deviations that vary systematically with observed inventor characteristics are captured by $X 2 \gamma 2 . X 2$ include inventor characteristics such as whether the inventor is foreign. If the BPAI has a "foreign bias," then the coefficient before the foreign variable should be statistically different from zero. $\varepsilon$ reflects deviations in the BPAI ruling that are idiosyncratic to the specific interference case. Lastly, $Z 2$ are the characteristics that do not vary across inventors that affect BPAI priority rulings. Similar to $Z 1$ earlier, $Z 2$ has no bearing in our analysis as $Z 2$ affects both $\alpha$ and $\beta$ equally.

We observe only the sign of $\alpha-\beta$ (i.e., who wins), and never observe the actual invention dates $a$ and $b$. Consequently, we estimate the key parameters $(\gamma 1, \gamma 2)$ using a probit regression on whether the junior party wins, and substitute from equations (4.4), (4.5) and (4.7) for $a$ and $b$.

Let $Y^{*}=\alpha-\beta$ and $Y=1$ if $Y^{*} \geq 0$ (and $Y=0$ if $Y^{*}<0$ ). $Y$ is a binary variable indicating whether the junior party has an earlier legal invention date and consequently wins the interference.

\footnotetext{
${ }^{24}$ Interference settlements assign property rights to a single party, and are approved by the BPAI. Here, settlements are treated as equivalent to a BPAI ruling where the "winner" is the settled assignee, and "BPAI ruling" refers to the party who is assigned rights to the interference count. This view is consistent with the assumption that settlements reflect the expectation of parties about what the BPAI decision would have been. In other work we are modeling the settlement/litigate decision jointly with the property right assignment outcome.
} 
When the incumbent is the senior party, we obtain:

$$
Y^{*}=\alpha-\beta=(i-c)+\left(X 2_{I}-X 2_{C}\right) \gamma 2+\left(\varepsilon_{I}-\varepsilon_{C}\right)
$$

or, letting $I=A, C=B, t_{I}=f$ and $t_{C}=g$ :

$$
Y^{*}=(f-g)-\left(X 1_{A}-X 1_{B}\right) \gamma 1+\left(X 2_{A}-X 2_{B}\right) \gamma 2+\left(\varepsilon_{A}-\varepsilon_{B}\right)
$$

If the incumbent is the junior party, then

$$
\begin{aligned}
& Y^{*}=\alpha-\beta=(c-i)+\left(X 2_{C}-X 2_{I}\right) \gamma 2+\left(\varepsilon_{C}-\varepsilon_{I}\right) \\
& =\left(t_{C}-X 1_{C} \gamma 1-Z 1 \omega 1\right)-\left((1 / \theta) t_{I}-((1-\theta) / \theta) t_{C}-X 1_{I} \gamma 1-Z 1 \omega 1\right) \\
& +\left(X 2_{C}-X 2_{I}\right) \gamma 2+\left(\varepsilon_{C}-\varepsilon_{I}\right) \\
& =(1 / \theta)\left(t_{C}-t_{I}\right)-\left(X 1_{C}-X 1_{I}\right) \gamma 1+\left(X 2_{C}-X 2_{I}\right) \gamma 2+\left(\varepsilon_{C}-\varepsilon_{I}\right)
\end{aligned}
$$

As the incumbent is the junior party, $C=A, I=B, t_{C}=f$, and $t_{I}=g$. Rewriting equation (4.10):

(4.11) $Y^{*}=(1 / \theta)(f-g)-\left(X 1_{A}-X 1_{B}\right) \gamma 1+\left(X 2_{A}-X 2_{B}\right) \gamma 2+\left(\varepsilon_{A}-\varepsilon_{B}\right)$

If neither inventors are incumbents, then

(4.12) $Y^{*}=\alpha-\beta=(f-g)-\left(X 1_{A}-X 1_{B}\right) \gamma 1+\left(X 2_{A}-X 2_{B}\right) \gamma 2+\left(\varepsilon_{A}-\varepsilon_{B}\right)$

Combining (4.9), (4.11), and (4.12) gives the latent estimation equation:

$$
\begin{aligned}
Y^{*}= & (1-\delta)(f-g)+\delta(1 / \theta)(f-g)-\left(X 1_{A}-X 1_{B}\right) \gamma 1+\left(X 2_{A}-X 2_{B}\right) \gamma 2 \\
& +\left(\varepsilon_{A}-\varepsilon_{B}\right)
\end{aligned}
$$

where $\delta=1$ when the incumbent is the junior party and $\delta=0$ when the senior party is an incumbent or neither party is incumbent.

Let $v=\left(\varepsilon_{A}-\varepsilon_{B}\right)$. We assume that $v$, conditional on the observed $(f, g, X 1, X 2)$, is distributed i.i.d. Normal with mean zero and finite variance across the interference cases. This i.i.d. assumption can be relaxed but not without sacrificing computational 
tractability. $^{25}$

Given the above, the probability that the junior party (B) wins is:

$$
\begin{aligned}
& \operatorname{Prob}\{Y=1 \mid f, g, X 1, X 2\}=\operatorname{Prob}\left\{Y^{*} \geq 0 \mid f, g, X 1, X 2\right\} \\
& =\operatorname{Prob}\left\{v \geq\left(X 1_{A}-X 1_{B}\right) \gamma 1-\left(X 2_{A}-X 2_{B}\right) \gamma 2-(1-\delta)(f-g)-\delta(1 / \theta)(f-g)\right\} \\
& =\Phi\left[\left\{(1-\delta)(f-g)+\delta(1 / \theta)(f-g)-\left(X 1_{A}-X 1_{B}\right) \gamma 1+\left(X 2_{A}-X 2_{B}\right) \gamma 2\right\} / \sigma\right]
\end{aligned}
$$

where $\delta=1$ when the incumbent is the junior party and $\delta=0$ otherwise.

Because $\alpha-\beta$ is not observed, $\sigma$ cannot be estimated. ${ }^{26}$ Following standard convention, we set $\sigma=1$. After normalizing $\sigma$, the coefficient before $(1-\delta)(f-g)$ need not be one. Therefore, we estimate the following

(4.15) $\operatorname{Prob}\{Y=1 \mid f, g, X 1, X 2\}$

$$
=\Phi\left[(1-\delta) \tau(f-g)+\delta(1 / \theta) \tau(f-g)-\left(X 1_{A}-X 1_{B}\right) \tau \gamma 1+\left(X 2_{A}-X 2_{B}\right) \tau \gamma 2\right]
$$

The estimated coefficient before $(1-\delta)(f-g)$ gives an estimate for $\tau$, and the ratio of the estimated coefficients before $\left(X 1_{B}-X 1_{A}, X 2_{A}-X 2_{B}\right)$ and the difference in filing dates $(f$ $-g)$ for cases where the junior party is not an incumbent provides an estimate for $(\gamma 1, \gamma 2)$.

Given the invariance property of maximum likelihood, the estimate of $(\gamma 1, \gamma 2)$ is consistent but inference requires the use of asymptotic non-linear hypothesis testing.

\section{Incumbency and the impact of patent races on innovation: estimations}

\footnotetext{
${ }^{25}$ For example, $\varepsilon$ could cluster by technology classes. This would imply a non-trivial covariance structure for $v$ and a simulation based estimation scheme. The differencing strategy implies greater flexibility for our assumptions, as factors in common $-Z 1$ and $Z 2$ - are implicitly accounted for. The mean zero assumption only relies on the proposition that the conditional means of $\varepsilon$ do not vary between the two inventors, leaving us with $\mathrm{E}\left(\varepsilon_{A}-\varepsilon_{B} \mid f, g, X 1, X 2\right)=0$. The i.i.d. assumption requires that the unobserved (inventor varying) factors, $\varepsilon$, affecting patent filing are themselves distributed i.i.d. across inventions and inventors.

${ }^{26}$ This is the usual scale problem associated with discrete choice models. See Train (2003) section 2.5
} 
A number of case and party characteristics influence the outcome of a priority dispute. Characteristics that affect the filing process and make-up $X 1$ are measures of the incumbency and size of the assignee firms. Characteristics that affect the BPAI ruling and make-up $X 2$ reflect institutional and bureaucratic features of the BPAI and the patent interference process. We explain the role of each below.

\subsection{Size and strategy $-X 1$}

The two components of X1 are size and incumbency. If the claim about dilatory small parties is correct, then small parties should be disproportionately successful. A small party, even as junior party, is likely to have invented first relative to larger firms who move to file with dispatch. Alternatively, if large firms have - and seize - the opportunity to delay filing relative to smaller firms due to the liquidity constraints discussed above, or if they are advantaged in litigation, then ceteris paribus, they will be disproportionately successful.

The model allows only a test for the dominating factor among the two size hypotheses. A zero coefficient could mean neither or both is present - conclusions with separate policy implications. If the effects cancel out in the current patent regime, then large firms will be more successful if the U.S. moves to a first-to-invent regime, because their delay is voluntary whereas that of the small firm is not.

The patent portfolio data for each applicant at the time the interference is declared is a proxy for size. The portfolios are adjusted to first, reflect average portfolio rates for all assignees who patent in the technology category ${ }^{27}$ and second to have an overall mean of one. We also consider two alternative size specifications. The first is for firms who

\footnotetext{
${ }^{27}$ Average portfolios are based on assignees in the NBER database. The winning patent's primary class identifies the technology category of each case.
} 
claim "small entity status" in their patent filings. Entity status is based on the Small Business Administration employee-based measure; firms that qualify are eligible for reduced filing fees. ${ }^{28}$ The second is for individual inventors versus applications assigned to corporations or governments. The variable included in the estimation for each definition of size measures the difference between the junior and senior party.

The strategic argument implies that incumbent firms should be disproportionately successful relative to challengers because they hold off filing for a patent even when they have an invention in hand. Our data do not allow a direct measure of incumbency, so instead we construct an index that measures the likelihood that a firm is incumbent. The senior party is potentially incumbent when he bases priority on a parent application. These are a subset of the cases declared "for" the senior party. We assume that when priority is based on a foreign patent the senior party is not an incumbent. The junior party is a potential incumbent when the case is not "for" the senior party, that is, when the senior party has neither a parent patent or foreign patent priority claim. Potential incumbents are more likely to be actual incumbents if they are large. Thus the incumbency index is a product of the technology-adjusted patent portfolio size for the firm and a dummy variable indicating when either the junior or senior party is a potential incumbent.

The filing difference variables require a bivariate measure of incumbency. Let the junior party be incumbent if, as before, the senior party does not base its priority claim on a parent or foreign patent, and in addition, if the junior party's patent portfolio exceeds that of the senior party. Finally, the incumbent must observe the senior party's

\footnotetext{
${ }^{28}$ Non-profit institutions, including universities, have inconsistent entity status, depending on what they plan to do with the patent in question. They are included in the "large" category. In estimations not reported here we tested whether they had any advantage in an interference, but found no systematic effects.
} 
patenting activity, so we require that the senior party have a patent at the time the interference is declared. ${ }^{29}$ The resulting interaction term identifies ten percent of the sample as cases where the junior party might moderate the extent to which he delays filing due to strategic considerations.

\subsection{Institutional features $-X 2$}

Institutionally, the junior party has the burden of proof, and hence is at a disadvantage in all of these cases. ${ }^{30}$ The key institutional control for this dataset is whether the firms are domestic or foreign. During this period certain kinds of priority evidence had to be based on activities in the United States, so that foreign firms were formally disadvantaged in their attempts to establish first inventorship. ${ }^{31}$

Included in $X 2$ is a variable that measure the number of citations in the patent that wins the interference. Citations in a patent relate the patent to previous technology and delineate the extent of the patent-holders' rights and provide a measure of the extent to which a patent derives from previous inventions (many citations) or is a less derivative work (few citations).

The optimal method to reduce an invention to practice and prepare an application is more likely to be known to both inventors for a highly-citing patent, as the underlying technology for such patents is well-understood. Consequently, there is no (good) reason for the elapsed time between invention dates and filing dates to differ between the parties.

\footnotetext{
${ }^{29}$ Alternatively, we could assume that the JP observes filing dates for SP prior to patent issuance, and include these cases as well in the incumbency interaction term. The results are qualitatively similar, with an estimate of $\sigma$ closer to one, consistent with a noisier measure of incumbency.

${ }^{30} \mathrm{~A}$ further burden is imposed on the junior party if his application was filed after the senior party's patent is issued; however, our data are currently too sparse to control for this problem.

31 This situation was changed in 1996, but the discriminatory clauses remained in effect for evidence about inventions that pre-dated the change, which includes all of the cases in our sample. We tested for whether the decision boards ruled more favorably towards foreign firms after the policy change, but found no statistical support for a change.
} 
Alternatively, the elapsed time for a patent with few citations could easily differ between two inventors, as one might pursue more dead-ends than the other. Thus the BPAI is likely to be more receptive to a due diligence argument from junior parties when the invention has few citations than the converse so that the number of citations will be negatively correlated to the likelihood that a junior party wins the interference.

\subsection{Bureaucratic and technological controls $-X 2$}

Bureaucratic reluctance to admit error might confer an advantage on a patentee. While no formal advantage is given to patented status, an adverse decision in an interference will reverse a previous ruling of the USPTO. Dummy variables are included for when a party has a patent, rather than application, in interference.

To the extent that filing and ruling differences across technology categories do not systematically differ across inventors (so are part of $Z 1$ or Z2), technology category dummies should have no predictive power. However, if the BPAI employs different standards to assess the claims of junior and senior parties by technology class, then they may belong in $X 2$. For example, patenting in new areas may be subject to a more relaxed standard of evidence, which would favor junior parties.

\subsection{Filing dates}

The filing dates, $f$ and $g$, are the benefit dates assigned to each party in the interference declaration, or the relevant filing dates for the count rather than the filing dates for the patent in interference. The former dates are the targets for litigation, e.g., the junior party must prove that he invented prior to the benefit date of the senior party rather than the date that the senior party filed for the patent in interference. The senior party always has an earlier priority date, so that the difference is always negative. 
According to the model developed in section 4, the associated coefficient should be positive. Sample statistics are contained in Table 10.

\section{Who innovates first: results}

The results confirm the existence of strategic delay by incumbents in each of the specifications (see tables 11 and 12). The Wald test statistics for significance of the ratio of the coefficient for incumbency to the coefficient for the difference in filing dates for the first specification in Table 11 is 5.22, which is significant at the 0.02 level. The analogous test statistics for the two probit regressions in Table 12 are 3.13 and 3.29, significant at the 0.08 and .07 levels.

Interpreting the magnitude of this coefficient is not straightforward. The variable is intended to capture the likelihood that the junior party is an incumbent. A standard deviation increase in that measure is associated with about an eight percent increase in the likelihood that the junior party will be successful, roughly equivalent to his increased likelihood of success from a one-year reduction in the filing difference between the parties. This in turn implies a lag between invention and filing of an additional year, or, equivalently, that his invention date is a year earlier than we would expect given his filing date and other characteristics. ${ }^{32}$ Of course, there might be good reasons for the lag other than elective delay; what our analysis measures is simply that it took extra time, for some reason, for such junior parties to file a patent application.

The ratio of the two filing difference coefficients yields an estimate for $\theta$ of

\footnotetext{
${ }^{32}$ The relevant filing difference coefficient is from the second specification in Table 11 as the incumbencydifference variable pertains to all junior parties rather than the subset identified in the JP-incumbent filing difference variable in the first specification.
} 
approximately one-third. ${ }^{33}$ We can estimate the extent to which the patent race moderates delay from this estimate. Rewriting equation (4.6) where the incumbent is a junior party and the challenger is the senior party:

$$
\begin{aligned}
& g=\theta t_{I} *+(1-\theta) f \\
& t_{I}^{*}-g=(1 / \theta) g-g-((1-\theta) / \theta) f=((1-\theta) / \theta)(g-f)
\end{aligned}
$$

Absent competition, the incumbent would have delayed filing by an addition amount $\left(t_{I}^{*}-g\right)$ - equal to the actual filing difference multiplied by $((1-\theta) / \theta)$. The average filing difference for cases that fit this profile (junior party incumbent according to the criteria listed above) is 1.14 years. Substituting in one-third for $\theta$ gives a multiple of two. Thus the impact of the patent race on filing is to accelerate the filing of the incumbent on average by two years.

Larger firms, other than those identified as incumbents, do not have an advantage in these cases: indeed, controlling for incumbency, smaller firms are more successful, which implies that they are slower to file for a patent than are larger firms. However, the analysis provides only weak support for the claim by proponents of the U.S. system that first-to-invent encourages invention by small firms, start ups, or individual inventors. The variables measuring these independent inventors and (formally) "small" firms are insignificant in all specifications (table 12). Furthermore, as discussed above, nearly all firms involved in interferences are very large indeed. Thus the coefficient on the patent portfolio variable reflects an advantage of large over very large firms, rather than small over large. Note also that the magnitude of the effect is modest: a standard deviation decrease in the portfolio size of the junior party relative to the senior party increases his

\footnotetext{
${ }^{33}$ The final column in table 11 reports for comparison the estimation with a single filing difference coefficient.
} 
chances of winning by four percent.

The results also reveal other interesting characteristics of the interferences. When the senior party has a patent, his chance for success increases by $10 \%$, even though the formal burden of proof is identical in these cases to the all-applicant alternative. Junior party patentees are not similarly advantaged.

The BPAI supports junior party patentees when their opponent bases his claim on a foreign patent, as is the case in a significant fraction of the cases where the junior party has a patent. Here, the junior party obtains a net benefit of thirteen to fifteen percent by virtue of his opponent. A senior party patentee going up against a foreign junior party is in great shape: the combination of a patent and a foreign opponent increases his chance of success by over $25 \%$. Worst off are junior parties who are not only foreign but also defending a foreign benefit date, which imposes an additional penalty of $9 \%$. Overall, foreign parties are deeply disadvantaged in these cases. Whether the new regulations are more equitable is an important area for study.

Finally, while none of the technology categories are distinguished in the estimate $^{34}$, the citation measure makes a difference: each subtracted citation makes it a half percent more likely that the junior party will win. A standard deviation decrease in patent citations increases the likelihood that the junior party wins by $6 \%$. Thus, it appears that the order of inventors and filers are likely to diverge - and inventors file second - for less derivative inventions.

\section{Conclusions.}

\footnotetext{
${ }^{34}$ In estimations not reported, inclusion of the technology categories are individually and jointly insignificant.
} 
The patent race literature emphasizes positive rather than normative results: it analyzes incentives to increase investment or speed up invention rather than absolute changes in efficiency. Incomplete property rights in invention mean that private investment, ignoring strategic considerations, is typically too low. Thus whether a patent race ameliorates underinvestment, corrects for it, or overshoots it depends on the strength of patent rights and other features that are difficult to observe or measure. While our results do not attempt to measure the welfare consequences of patent racing, they illustrate its two edges.

On one hand, if patent races are common - and we calculate that in certain technology categories they may be pervasive - then the investment in research may be inefficient. The argument for the need for strong patent rights to support expensive research can be turned upside-down: rather, the results suggest that in some fields strong patent rights might induce, rather than support expensive research, and not necessarily with an increase in research productivity.

Alternatively, our results also illustrate the salutory effect of a race on innovation. While all firms may have an incentive to race to invent, we show that incumbent firms prefer to delay filing a patent application. Competition for a patent cuts back on the benefits to delay, spurring innovation. The less forgiving nature of the first-to-file system would presumably intensify the race to file as well as the race to invent.

This study offers some preliminary conclusions about how the first-to-invent and first-to-file patent systems differ in priority grants. Assuming we prefer to reward inventors with a patent, rather than speedy filers, our study suggests that first-to-file will make more mistakes on inventions that are more innovative. In consequence, the first-to- 
invent system may in fact provide better incentives for fundamental invention than a firstto-file system.

Like other critics, we do not find evidence that the system works to the benefit of small inventors or firms. Small firms rarely avail themselves of the interference process. But if we assume that the winner of an interference is the first-to-invent, the results suggest that small inventors do not suffer from a filing disability. Alternatively, there is some indication that other groups do have such problems - both the U.S. government and U.S. universities, for example, are far more likely to enter our sample as junior parties, yet they win a reasonable share of cases, which suggests that both institutions systematically take longer to file patent applications than do private firms and individuals. However, we need more data to establish the trend statistically. A troubling consequence of the first-to-invent system is that it lightly penalizes firms that are slow to file, as long as they are not too slow. Instead of being used by virtuous small inventors, our data suggest that the system supports strategic incumbents who wish to defer filing for a patent, possibly deferring innovation and certainly deferring divulging the details of their innovations in patent filings and the dissemination of the information that the patent system requires as a quid pro quo for temporal exclusivity. 


\section{References}

Acs, Zoltan J. and David B. Audretsch, 1988. "Innovation in Small and Large Firms: An Empirical Analysis," American Economic Review, 78: 678-690.

Arrow, Kenneth, 1962. "Economic Welfare and the Allocation of Resources for Innovation," in Nelson, editor, The Rate and Direction of Inventive Activity, Princeton University Press.

Calvert, Ian A. and Michael Sofocleous, 1989. "Interference Statistics for Fiscal Years 1986 to 1988," Journal of the Patent and Trademark Office Society, 71 JPTOS 399.

Calvert, Ian A. and Michael Sofocleous, 1992. "Interference Statistics for Fiscal Years 1989 to 1991," Journal of the Patent and Trademark Office Society, 74 JPTOS 822.

Calvert, Ian A. and Michael Sofocleous, 1995. "Interference Statistics for Fiscal Years 1992 to 1994," Journal of the Patent and Trademark Office Society, 77 JPTOS 417.

Cockburn, Iain and Rebecca Henderson, 1994. "Racing to Invest? The Dynamics of Competition in Ethical Drug Discovery," Journal of Economics \& Management Strategy, 3 (3): 481-519.

Cohen, Wesley M., Richard R. Nelson and John Walsh, 1997. “Appropriability Conditions and Why Firms Patent and Why They Do Not in the American Manufacturing Sector," mimeo.

Czarnitzki, Dirk and Kornelius Kraft, 2004. “An empirical test of the asymmetric models on innovative activity: who invests more into R\&D, the incumbent or the challenger?" Journal of Economic Behavior \& Organization, 54: 153-173.

Gholtz, Charles L., 2000. "First-to-File or First-to-Invent?” Journal of the Patent and Trademark Office Society, 82 JPTOS 891.

Gholtz, Charles L, 2001. "Parallel District Court and ITC Patent Infringement Actions and PTO Interferences," Patent World, April, 2001, p. 19.

Hall, Bronwyn H., Stuart J.H. Graham, Dietmar Harhoff, and David C. Mowery, 2003. "Prospects for Improving U.S. Patent Quality via Post-grant Opposition," in Innovation Policy and the Economy, vol 4, pp. 115-143.

Jaffe, Adam B. and Josh Lerner, 2004. Innovation and Its Discontents: How our broken patent system is endangering innovation and progress and what to do about it, Princeton University Press.

Jaffe, Adam B. and Manuel Trajtenberg, 2002. Patents, Citations \& Innovations: A Window on the Knowledge Economy, MIT Press. 
Kingston, William, 2004. "Light on Simultaneous Invention from U.S. Patent Office 'Interference' Records," World Patent Information, 26: 209-220.

Kingston, William, 1995. "Reducing the Cost of Resolving Intellectual Property Disputes," European Journal of Law and Economics, 2: 85-92.

Kingston, William, 2000. "Compulsory Arbitration - Empirical Evidence," European Intellectual Property Review, 22 (4) 154-158.

Lanjouw, Jean O. and Josh Lerner, 1998. "The Enforcement of Intellectual Property Rights: A Survey of the Empirical Literature," Annales d'Economie et de Statistique, 4950: $223-246$.

Lanjouw, Jean O. and Josh Lerner, 2001. "Tilting the Table? The Predatory Use of Preliminary Injunctions," The Journal of Law and Economics, 44(2): 573 - 603.

Lanjouw, Jean O. and Mark Schankerman, 2001. "Characteristics of Patent Litigation: a Window on Competition," Rand Journal of Economics 32 (1):129-151.

Lanjouw, Jean O. and Mark Schankerman, forthcoming. "Protecting Intellectual Property Rights: Are Small Firms Handicapped?” Journal of Law and Economics.

Lanjouw, Jean O., Ariel Pakes and Jonathan Putnam, 1998. "How to Count Patents and Value Intellectual Property: The Uses of Patent Renewal and Application Data," Journal of Industrial Economics, 46 (4); pp 405-432.

Lemley, Mark A. and Colleen V. Chien, 2003. "Are the U.S. Patent Priority Rules Really Necessary?" Hastings Law Journal, 54 Hastings L.J. 1299.

Lemley, Mark, 2001. "Rational Ignorance at the Patent Office," Northwestern University Law Review, Vol. 95:1495.

Lerner, Josh, 1997. “An Empirical Exploration of a Technology Race,” RAND Journal of Economics, 28 (2); 228-247.

Lipscomb III, Ernest Bainbridge, 1986. Lipsomb's Walker on Patents, third edition, Volume 4, Chapter 13. The Lawyers Cooperative Publishing Co.

Mossinghoff, Gerald J., 2002. "The U.S. First-to-Invent System Has Provided No Advantage to Small Entities," Journal of the Patent and Trademark Office Society 88 JPTOS 425.

Priest, George and Benjamin Klein, 1984. "The Selection of Disputes for Litigation," Journal of Legal Studies, vol 13, 1 - 55. 
Reinganum, Jennifer F. 1989, "The Timing of Innovation: Research, Development, and Diffusion," Chapter 14 in Handbook of Industrial Organization, Vol I edited by Kenneth J. Arrow and Michael D. Intriligator, North Holland Press, (Amsterdam).

Reinganum, Jennifer F., 1982, “A Dynamic Game of R and D: Patent Protection and Competitive Behavior," Econometrica, 50(3): 671-88.

Schankerman, Mark, 1998. "How Valuable is Patent Protection? Estimates by Technology Field," Rand Journal of Economics, 29:1, pp. 77 - 107.

Train, Kenneth E, 2003. Discrete Choice Methods with Simulation, Cambridge University Press. 
APPENDIX A: Estimating the rate of interference

Define the following terms:

$A_{t}, t=\{1, \ldots n\}$ is the number of applications filed in period $t$. (All of the definitions and conditions discussed here refer to a single technology class.)

$I_{t}, t=\{1, \ldots n\}$ is the number of applications filed in period $t$ that are involved in an interference at some later time (also called "interfered applications").

$D_{t, s}, s=\{0, \ldots, n-1\}$ is the number of interfered applications from period $t$ that are declared in period $t+s$. All interferences are declared within $n-1$ periods of the filing of the application.

$\alpha_{t, s}$ equals the share of interfered applications from period $t$ that are declared in period $t+s$.

Thus:

$$
D_{t, 0}+D_{t, 1}+\ldots+D_{t, n-1}=I_{t} ; \quad \alpha_{t, 0}+\ldots+\alpha_{t, n-1}=1 ; \text { and } \alpha_{t, s} I_{t}=D_{t, s}
$$

Assume that the following conditions hold within technology categories:

Assumption 1: The rate of interfering is constant, i.e., $I_{t} / A_{t}=r$ for all $t \varepsilon\{1, \ldots, n\}$. We are interesting in calculating $r^{35}$

Assumption 2: The distribution of declaration dates for interfered applications is identical for applications filed in each period, i.e., $\alpha_{t, s}=\alpha_{v, s}=\alpha_{s}$ for all $t, v \varepsilon\{1, \ldots, n\}$.

Our sample consists of all interferences declared during period $n$. In period $n$ we observe $\left\{D_{1, n-1}, D_{2, n-2}, \ldots, D_{n, 0}\right\}$. Substituting from the above definitions:

$$
\begin{aligned}
& D_{1, n-1} / A_{1}+D_{2, n-2} / A_{2}+\ldots+D_{n, 0} / A_{n}=\alpha_{n-1} I_{1} / A_{1}+\alpha_{n-2} I_{2} / A_{2}+\ldots+\alpha_{0} I_{n} / A_{n} \\
& =\alpha_{n-1} r+\alpha_{n-2} r+\ldots+\alpha_{0} r=r
\end{aligned}
$$

\footnotetext{
${ }^{35}$ We abstract from patent office policy changes and exogenous changes in research activities. Our conclusions rest on large differences among the rates, rather than subtle changes that would perhaps be overwhelmed by possible changes in PTO policies during this period.
} 
Hence, we can recover the rate of interference by summing the weighted interfered applications from each prior period that are in interferences declared during a single period, where the weights correspond to the inverse of the total number of applications filed during the same year as the interfered applications.

The six years of interference declarations are broken into two 3-year periods to better capture the changes in the number of applications per category over time. This gives two estimates of the rate, one for each subperiod, so that the calculated rate for each technology (column) is obtained as follows:

rate (for each column) $=1 / 2\left(\sum_{t, s}\left(D_{t s} / A_{t s}\right)\right)$, where $D_{t s}$ are the entries in the top part of the matrix and $A_{t s}$ in the lower part.

The sample includes $46.1 \%$ of all the interferences filed in this period, and estimates are accordingly inflated to account for the larger population of interferences. Omitted from the sample are interference design patent cases (less than 1\%) and cases whose declaration was accelerated to 1987 or delayed beyond 1993.

Note that we use applications that mature to a patent, rather than all applications, in the denominator of our calculations. There are roughly twice as many applications as patents, so using the latter standard would reduce the rates by half, and the relative incidence rate, of greatest interest for this paper, would remain unchanged. We believe that the subset of applications that mature is a better measure for our purposes. These applications are the set of patentable inventions that arrive at the PTO. Each application in interference is in that set - except for the fact of the interference itself. Interferences are only allowed among "patentable inventions" (see footnote 15, above). In fact, out of the total sample of interferences less than eight percent resulted in no patent (coded as 
"both lose" in Table 2) and we suspect that if not for the interference they probably would have passed muster - indeed $75 \%$ of those cases started out with either the junior party or the senior party having a patent, from which the count or entire patent was invalidated in the course of the litigation.

APPENDIX B: Filing Strategies.

Cases I: neither party is an incumbent. Then $\mathrm{f}=\mathrm{TA} ; \mathrm{g}=\mathrm{TB}$, and

$$
\alpha-\beta=(f-g)+\left(X_{B}-X_{A}\right) \gamma-Y_{A} \gamma^{S P}+Y_{B} \gamma^{J P}
$$

Case II: One party is incumbent, the other is not.

The incumbent's utility for filing at time $t$ is given by a quadratic loss function:

$\mathrm{U}(\mathrm{t})=-\theta\left(\mathrm{t}-\mathrm{t}_{\mathrm{I}}{ }^{*}\right)^{2}-(1-\theta)(\mathrm{t}-\mathrm{f})^{2}$ if the incumbent is the junior party, where $0<\theta \leq 1$ $-\left(t-t_{1}^{*}\right)^{2}$ if the incumbent is the senior party

Lemma: Suppose the challenger files at time $h$. The incumbent will choose to be the senior party if and only if $t_{1}^{*}<h$.

Proof: Clearly, if $\mathrm{t}_{\mathrm{I}} *<\mathrm{h}$, then the incumbent will file at $\mathrm{t}_{\mathrm{I}} *$ and be the senior party. So, suppose that $t_{1}^{*}>h$.

The incumbent can be the senior party by pre-empting the junior party, $\mathrm{t}<\mathrm{h}$. The derivative of the utility function of the incumbent as a senior party is $U^{\prime}(t)=-2\left(t-t_{1}^{*}\right)>$ 0 for all $\mathrm{t}<\mathrm{h}<\mathrm{t}_{1}{ }^{*}$. Therefore, conditional on deciding to pre-empt the junior party, the optimal choice of $\mathrm{t}$ for the incumbent is $\mathrm{h}-\Delta$, for an arbitrarily small $\Delta$.

The incumbent is the junior party for any choice of $t>h$. The derivative of the utility function of the incumbent as a junior party is $\left.U^{\prime}(t)\right|_{t=h}=-2 \theta\left(t-t_{1}^{*}\right)>0$ (note that this is the limiting derivative from above and below) Hence, the incumbent will choose a 
value $t$ greater than $h$. From the first order condition, the optimal $t *$ for the incumbent conditional on being a junior party, is $t^{*}=\theta t_{1}^{*}+(1-\theta) h$.

Given $\mathrm{t}_{1} *>\mathrm{h}$ and $\Delta \rightarrow 0$, the optimal utility for the incumbent from being a senior

party, $-\left(h-\Delta-t_{1} *\right)^{2}$, is less than the optimal utility from being a junior party, $-\theta(1-\theta)\left(t_{1}{ }^{*}-\right.$

h) $)^{2}$. Therefore, the incumbent always prefers to be the junior party when $t_{1}^{*}>h$.

Case IIa: The senior party is incumbent. Then

$$
\begin{aligned}
& t_{I}=t_{I}^{*}=T_{A} \\
& t_{C}=t_{C} *=T_{B}
\end{aligned}
$$

Case IIb: The junior party is incumbent. Then B maximizes:

$$
\begin{aligned}
& U(t)=-\theta\left(t-t_{I}^{*}\right)^{2}-(1-\theta)(t-f)^{2} \\
& U^{\prime}(t)=-2 \theta\left(t-t_{I}^{*}\right)-2(1-\theta)(t-f) \\
& t_{I}=\theta t_{I}^{*}+(1-\theta) f>f
\end{aligned}
$$

\section{Appendix C: Data Sources}

The unit of observation for this study is an interference case. Unfortunately, information concerning interference cases can only be obtained on a case-by-case basis from physical files maintained by the USPTO at the File Information Unit (FIU) in Arlington, Virginia. As a consequence, we chose to use a random sample of the interference cases initiated by the BPAI between 1988 and 1994. Interference cases during this period were assigned consecutive case numbers between 101,850 and 103,300 . The case numbers are approximately chronological, with a few exceptions. We constructed a random list of 725 case numbers from the possible 1451 (50\%). We put in the file request at the FIU for each of these drawn case numbers. 
For each successful file request, we collected the Interference Declaration, which identifies the parties, their priority dates, any assignees, addresses, counts, the patent or application claims that correspond to the counts, and the final judgment or final decision in each case. We also obtained the dates for the declaration and case resolution, redeclarations, whether a final hearing was held, and other miscellaneous information. We use the original designation of parties when they switch in the course of the proceeding (that is, if the senior party is redesignated junior and vice versa). When the declaration omitted assignee information we checked the PTO assignee database, at http://assignments.uspto.gov/assignments/q?db=pat. We coded for assignees only if the application or patent was assigned during the interference period or, when ambiguous, if the inventor clearly had a long-standing relationship with the assignee.

Some files are incomplete. Interference dates and resolutions (but not priority dates, counts, or junior/senior designations) are also available from the USPTO External Patent Application Information Retrieval (PAIR) web site at http://portal.uspto.gov/external/portal/ . The PAIR database also includes information on entity status and foreign priority. Additionally, a subset of BPAI decisions is available at the USPTO-BPAI link and through the Westlaw and Lexis-Nexis administrative decisions database. In total, we were able to obtain sufficient information for 668 case numbers from the sampled total of 725 (92\%). For the remaining 57, the staff at the FIU provided us with the numbers of the applications involved in the interferences from the Internal PAIR database. We matched the numbers with external PAIR, and where possible, culled when and whether a patent was granted to the applicant, the beginning and ending interference dates, the interference outcome, and the technology category. 
The distribution of these case characteristics do not differ noticeably for the omitted cases, compared to the included cases.

Patent portfolio statistics are from the July 2005 Patent BIB DVD issued by the USPTO. We matched all assignees with their assignee code and then searched for patents issued between 1975 and the case declaration date. Using the same database, we searched for inventors' patents using name and address identifiers (city, state and/or country). Information on technology class and patent citations are from the winning patent. When a winning application is superceded by a second application including the count technology (a child patent) we obtained class and citation information from the child patent. We included a number of variables to capture possible trends in the patent portfolio and citation information (declaration date, winning patent date, patent application date) but found no significant trends in our sample. 
Table 1: Types of Interference Cases

\begin{tabular}{|c|c|c|c|c|}
\hline & \multicolumn{3}{|c|}{ Case Type } & \multirow[b]{2}{*}{ Total } \\
\hline & $\begin{array}{l}\text { All } \\
\text { Applicant }\end{array}$ & $\begin{array}{l}\text { SP } \\
\text { Patentee }\end{array}$ & $\begin{array}{l}\text { JP } \\
\text { Patentee }\end{array}$ & \\
\hline Senior party: & 0 & 136 & 0 & 136 \\
\hline \multicolumn{5}{|l|}{ Application } \\
\hline Only & 69 & 0 & 32 & 101 \\
\hline Foreign Patent & 85 & 0 & 228 & 313 \\
\hline Parent Patent & 34 & 0 & 84 & 118 \\
\hline $\begin{array}{l}\text { (First) Junior } \\
\text { Party: }\end{array}$ & 0 & 5 & 341 & 346 \\
\hline \multicolumn{5}{|l|}{ Application } \\
\hline Only & 105 & 67 & 0 & 172 \\
\hline Foreign Patent & 52 & 34 & 1 & 87 \\
\hline Parent Patent & 31 & 30 & 2 & 63 \\
\hline & $\begin{array}{c}188 \\
28.14 \%\end{array}$ & $\begin{array}{c}136 \\
20.36 \%\end{array}$ & $\begin{array}{c}344 \\
51.50 \%\end{array}$ & 668 \\
\hline
\end{tabular}




\begin{tabular}{|c|c|c|c|c|c|}
\hline \multicolumn{6}{|c|}{$\begin{array}{l}\text { Table 2: Distribution of Outcomes by Technology Category, } \\
\text { number and share }\end{array}$} \\
\hline $\begin{array}{l}\text { Technology } \\
\text { category: }\end{array}$ & $\begin{array}{l}\text { Senior } \\
\text { Party }\end{array}$ & $\begin{array}{c}\text { priority } \\
\text { Junior } \\
\text { Party }\end{array}$ & $\begin{array}{c}\text { ignment: } \\
\text { Both }\end{array}$ & None & $\begin{array}{l}\text { No. of } \\
\text { cases } \\
\text { Total }\end{array}$ \\
\hline Chemicals & $\begin{array}{c}112 \\
56.28 \%\end{array}$ & $\begin{array}{c}61 \\
30.65 \%\end{array}$ & $\begin{array}{c}18 \\
9.05 \%\end{array}$ & $\begin{array}{c}8 \\
4.02 \%\end{array}$ & 199 \\
\hline $\begin{array}{l}\text { Communications } \\
\& \text { Computers }\end{array}$ & $\begin{array}{c}21 \\
63.64 \%\end{array}$ & $\begin{array}{c}8 \\
24.24 \%\end{array}$ & $\begin{array}{c}2 \\
6.06 \%\end{array}$ & $\begin{array}{c}2 \\
6.06 \%\end{array}$ & 33 \\
\hline Drugs - total & $\begin{array}{c}96 \\
57.83 \%\end{array}$ & $\begin{array}{c}46 \\
27.71 \%\end{array}$ & $\begin{array}{c}18 \\
10.84 \%\end{array}$ & $\begin{array}{c}6 \\
3.61 \%\end{array}$ & 166 \\
\hline Biotech & $\begin{array}{c}23 \\
46.94 \%\end{array}$ & $\begin{array}{c}17 \\
34.69 \%\end{array}$ & $\begin{array}{c}9 \\
18.37 \%\end{array}$ & $\begin{array}{c}0 \\
0.00 \%\end{array}$ & 49 \\
\hline Med Equip & $\begin{array}{c}23 \\
71.88 \%\end{array}$ & $\begin{array}{c}4 \\
12.50 \%\end{array}$ & $\begin{array}{c}1 \\
3.13 \%\end{array}$ & $\begin{array}{c}4 \\
12.50 \%\end{array}$ & 32 \\
\hline Drugs-other & $\begin{array}{c}50 \\
58.82 \%\end{array}$ & $\begin{array}{c}25 \\
29.41 \%\end{array}$ & $\begin{array}{c}8 \\
9.41 \%\end{array}$ & $\begin{array}{c}2 \\
2.35 \%\end{array}$ & 85 \\
\hline Electrical & $\begin{array}{c}45 \\
68.18 \%\end{array}$ & $\begin{array}{c}15 \\
22.73 \%\end{array}$ & $\begin{array}{c}5 \\
7.58 \%\end{array}$ & $\begin{array}{c}1 \\
1.52 \%\end{array}$ & 66 \\
\hline Mechanical & $\begin{array}{c}64 \\
59.26 \%\end{array}$ & $\begin{array}{c}30 \\
27.78 \%\end{array}$ & $\begin{array}{c}6 \\
5.56 \%\end{array}$ & $\begin{array}{c}8 \\
7.41 \%\end{array}$ & 108 \\
\hline Other & $\begin{array}{l}52 \\
57.78 \%\end{array}$ & $\begin{array}{c}23 \\
25.56 \%\end{array}$ & $\begin{array}{c}3 \\
3.33 \%\end{array}$ & $\begin{array}{c}12 \\
13.33 \%\end{array}$ & 90 \\
\hline Total & $\begin{array}{c}390 \\
58.91 \%\end{array}$ & $\begin{array}{c}183 \\
27.64 \%\end{array}$ & $\begin{array}{c}52 \\
7.85 \%\end{array}$ & $\begin{array}{c}37 \\
5.59 \%\end{array}$ & 662 \\
\hline
\end{tabular}

\begin{tabular}{|l|ccc|}
\hline \multicolumn{4}{|c|}{$\begin{array}{c}\text { Table 3: Frequency of sample applicants } \\
\text { relative to all applicants, 1977 }\end{array}$} \\
& $\begin{array}{c}\text { Sample } \\
\text { frequency }\end{array}$ & $\begin{array}{c}\text { Sample } \\
\text { percent }\end{array}$ & $\begin{array}{c}\text { Population } \\
\text { percent }\end{array}$ \\
\hline & 767 & $55.82 \%$ & $41.41 \%$ \\
US Corp. & 366 & $26.64 \%$ & $36.79 \%$ \\
Foreign Corp. & 111 & $8.08 \%$ & $13.50 \%$ \\
US Indiv. & 59 & $4.29 \%$ & $1.40 \%$ \\
University & 36 & $2.62 \%$ & $5.07 \%$ \\
Foreign Indiv. & 15 & $1.09 \%$ & $1.34 \%$ \\
U.S. Govt. & 20 & $1.46 \%$ & $0.48 \%$ \\
Foreign Govt, & & & \\
NP & &
\end{tabular}

sources for Population Percents:

http://www.uspto.gov/web/offices/ac/ido/oeip/taf/h at.htm\#parta2 1b

http://www.uspto.gov/web/offices/ac/ido/oeip/taf/univ/univ toc.htm 


\begin{tabular}{|lcc|}
\hline \multicolumn{3}{|c|}{$\begin{array}{c}\text { Table 4: 1976-1999 Assignee Patent } \\
\text { Portfolios: Sample versus Population } \\
\text { (NBER data, assigned patents only) }\end{array}$} \\
\hline & $\begin{array}{c}\text { Sample (644 } \\
\text { matched } \\
\text { assignees) }\end{array}$ & $\begin{array}{c}\text { "Population" } \\
\text { (147,941 } \\
\text { assignees) }\end{array}$ \\
\hline Mean & 906.35 & 11.44 \\
Median & 110 & 1 \\
Std Dev & 2315.85 & 187.18 \\
Min & 1 & 1 \\
Max & 22011 & 22011 \\
Q75 & 624 & 3 \\
Q90 & 2302 & 9 \\
Q99 & 11882 & 119 \\
\hline
\end{tabular}

Table 5: 1991 Patent Portfolios: Comparison of Sample Assignees and All Assignees by Technology Category (NBER Data; assigned patents only)

\begin{tabular}{|c|c|c|c|c|c|c|}
\hline \multirow[b]{5}{*}{ Technology } & \multicolumn{3}{|c|}{ All Assignees in NBER database } & \multicolumn{3}{|c|}{ Sample Assignees } \\
\hline & & & Mean & & & \\
\hline & & & Portfolio, & & & Mean \\
\hline & & $\begin{array}{c}\text { Mean } \\
\text { Patents }\end{array}$ & $\begin{array}{l}\text { at least } \\
\text { one }\end{array}$ & & $\begin{array}{l}\text { Mean } \\
\text { Patents }\end{array}$ & $\begin{array}{l}\text { Portfolio, at } \\
\text { least one }\end{array}$ \\
\hline & & Within & patent in & & Within & patent in \\
\hline Category & $\mathrm{N}$ & Category & category & $\mathrm{N}$ & Category & category \\
\hline Chemicals & 20887 & 10.881 & 35.037 & 456 & 231.857 & 709.048 \\
\hline Communication/ & & & & & & \\
\hline Computers & 8980 & 9.747 & 65.419 & 263 & 155.099 & 1110.67 \\
\hline Drugs & 8525 & 7.236 & 58.821 & 338 & 75.355 & 838.941 \\
\hline Electrical & 18815 & 9.01 & 38.193 & 367 & 175.398 & 864.787 \\
\hline Mechanical & 33489 & 6.289 & 2999 & 423 & 134.225 & 757.355 \\
\hline Other & 38746 & 4.24 & 20.461 & 443 & 73.334 & 728.14 \\
\hline
\end{tabular}

Table 6: Per-case Mean Patent Portfolio at Declaration by Technology Category and Party

\begin{tabular}{|l|c|c|c|}
\hline & Junior Party & Senior Party & All \\
\hline Chemicals & 2,550 & 2,354 & 2,456 \\
Computers & 1,573 & 1,853 & 1,709 \\
Drugs & 877 & 737 & 814 \\
Electrical & 2,499 & 1,707 & 2,121 \\
Mechanical & 739 & 447 & 598 \\
Other & 664 & 661 & 663 \\
Total & 1,499 & 1,318 & 1,414 \\
\hline
\end{tabular}




\begin{tabular}{|l|ccc|}
\hline \multicolumn{4}{|c|}{$\begin{array}{c}\text { Table 7: Mean Patent Portfolio by Party and } \\
\text { Case Type (std. dev. }\end{array}$} \\
\hline type of case: & Junior Party & Senior Party & Freq. \\
\hline All Applicant & $1483(2728)$ & $1425(2773)$ & 181 \\
JP Patentee & $1565(2826)$ & $1404(2797)$ & 332 \\
SP Patentee & $1318(3047)$ & $911(2027)$ & 132 \\
Total & $1491(2840)$ & $1309(2655)$ & 645 \\
\hline
\end{tabular}

\begin{tabular}{|c|c|c|c|}
\hline \multicolumn{4}{|c|}{$\begin{array}{c}\text { Table 8: Interference and Infringement Rates by } \\
\text { Technology Category } \\
\text { (cases per thousand patented applications) }\end{array}$} \\
\hline & \multirow[t]{2}{*}{ Interference Rates } & \multicolumn{2}{|c|}{ Infringement Rates } \\
\hline & & {$[1]$} & [2] \\
\hline All & 6.27 & 10.7 & 19 \\
\hline Chemicals & 9.15 & 5.4 & 11.8 \\
\hline Computers & 3.04 & & 25.6 \\
\hline Drugs & 21.34 & 20.1 & \\
\hline Electrical & 3.47 & 9.6 & 15.4 \\
\hline Mechanical & 4.27 & 11.8 & 16.9 \\
\hline Other & 3.93 & 15.2 & 34.2 \\
\hline Biotech & 49.71 & & 27.9 \\
\hline Med Equip & 11.68 & & 34.6 \\
\hline $\begin{array}{l}\text { Drugs- } \\
\text { other }\end{array}$ & 20.23 & & 22.2 \\
\hline
\end{tabular}

(1) total for patent granted 1980 - 1984, Table 1, Lanjouw \& Schankerman (2001).

(2) total for patents granted 1978- 1995, Table 1, Lanjouw \& Schankerman (2004).

\begin{tabular}{|lccc|}
\hline \multicolumn{4}{|c|}{ Table 9: Relative Interference and Infringement } \\
Rates by Technology Category \\
(All = 1.00)
\end{tabular}




\begin{tabular}{|c|c|c|c|c|c|}
\hline \multicolumn{6}{|c|}{ Table 10: Sample Statistics } \\
\hline Variable & $\mathrm{N}$ & Mean/ *Share & $\begin{array}{l}\text { Std. } \\
\text { Dev }\end{array}$ & Min & Max \\
\hline JP win* & 584 & 0.32 & & 0.00 & 1.00 \\
\hline $\begin{array}{l}\text { difference in filing dates } \\
\text { in vears }\end{array}$ & 584 & -0.92 & 113 & -10.47 & م0 0 \\
\hline filing difference, JP & & & & & \\
\hline incumbent & 49 & -1.14 & 1.61 & -8.94 & 0.00 \\
\hline $\begin{array}{l}\text { filing difference, JP not } \\
\text { incumbent }\end{array}$ & 534 & -0.89 & 1.07 & -10.47 & 0.00 \\
\hline $\begin{array}{l}\text { Difference in } \\
\text { incumbency }\end{array}$ & 584 & 0.26 & 2.23 & -11.23 & 19.98 \\
\hline Backward citations & 584 & 10.60 & 10.38 & 0.00 & 74.00 \\
\hline JP patentee* & 584 & 0.52 & & 0.00 & 1.00 \\
\hline SP patentee* & 584 & 0.21 & & 0.00 & 1.00 \\
\hline SP foreign* & 584 & 0.36 & & 0.00 & 1.00 \\
\hline SP benefit foreign* & 584 & 0.34 & & 0.00 & 1.00 \\
\hline $\mathrm{JP}$ foreign* & 584 & 0.26 & & 0.00 & 1.00 \\
\hline JP benefit foreign* & 584 & 0.07 & & 0.00 & 1.00 \\
\hline JP inventor* & 584 & 0.10 & & & \\
\hline SP inventor* & 584 & 0.09 & & & \\
\hline JP small entity status* & 584 & 0.15 & & 0.00 & 1.00 \\
\hline SP small entity status* & 584 & 0.13 & & 0.00 & 1.00 \\
\hline $\begin{array}{l}\text { Difference in patent } \\
\text { portfolios, tech adjusted }\end{array}$ & 584 & 0.21 & 2.46 & -11.19 & 15.57 \\
\hline
\end{tabular}


Table 11: Probit Results for Strategic Filing Model

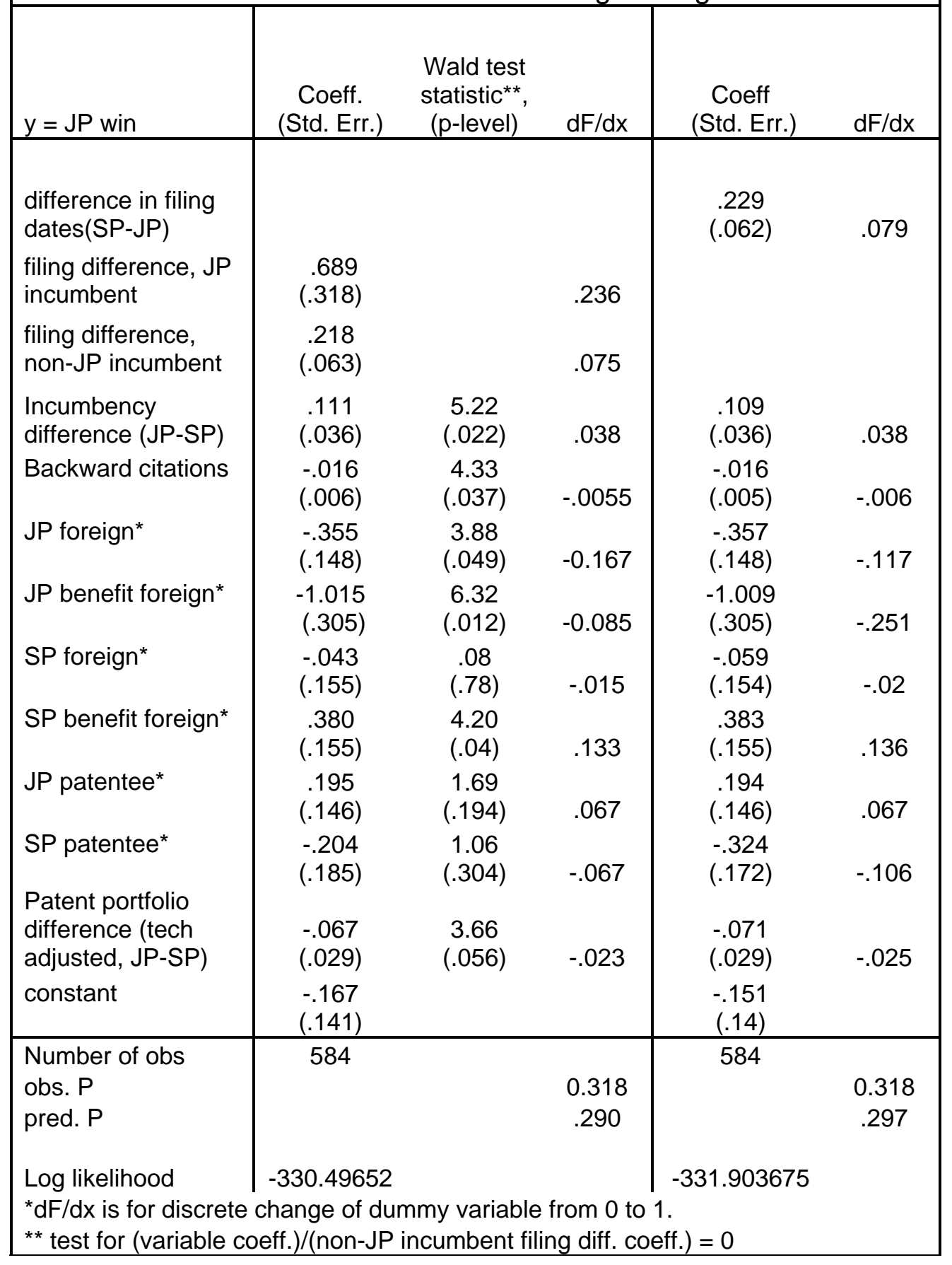


Table 12: Strategic Filing Probit Model, Alternative Size Specifications

\begin{tabular}{|c|c|c|c|c|}
\hline$y=J P$ win & $\begin{array}{l}\text { Coeff (Std. } \\
\text { Err.) }\end{array}$ & $\mathrm{dF} / \mathrm{dx}$ & $\begin{array}{l}\text { Coeff (Std. } \\
\text { Err.) }\end{array}$ & $\mathrm{dF} / \mathrm{dx}$ \\
\hline $\begin{array}{l}\text { filing difference, JP } \\
\text { incumbent }\end{array}$ & $\begin{array}{l}.704 \\
(.323)\end{array}$ & .254 & $\begin{array}{l}.735 \\
(.323)\end{array}$ & .252 \\
\hline $\begin{array}{l}\text { filing difference, non-JP } \\
\text { incumbent }\end{array}$ & $\begin{array}{l}.214 \\
(.063)\end{array}$ & .073 & $\begin{array}{l}.220 \\
(.063)\end{array}$ & .076 \\
\hline $\begin{array}{l}\text { Incumbency difference } \\
\text { (JP-SP) }\end{array}$ & $\begin{array}{l}.059 \\
(.028)\end{array}$ & .020 & $\begin{array}{l}.061 \\
(.028)\end{array}$ & .021 \\
\hline Backward citations & $\begin{array}{l}-.016 \\
(.006)\end{array}$ & -.005 & $\begin{array}{l}-.016 \\
(.006)\end{array}$ & -.005 \\
\hline JP foreign* & $\begin{array}{l}-.317 \\
(.145)\end{array}$ & -.103 & $\begin{array}{l}-.314 \\
(.145)\end{array}$ & -.103 \\
\hline JP benefit foreign* & $\begin{array}{l}-.99 \\
(.301)\end{array}$ & -.244 & $\begin{array}{l}-1.006 \\
(.301)\end{array}$ & -.246 \\
\hline SP foreign* & $\begin{array}{l}-.057 \\
(.154)\end{array}$ & -.019 & $\begin{array}{l}-.072 \\
(.154)\end{array}$ & -.024 \\
\hline SP benefit foreign* & $\begin{array}{l}-.317 \\
(.145)\end{array}$ & .135 & $\begin{array}{l}.404 \\
(.154)\end{array}$ & .143 \\
\hline JP Patentee* & $\begin{array}{l}.109 \\
(141)\end{array}$ & .037 & $\begin{array}{l}.114 \\
(.141)\end{array}$ & .039 \\
\hline SP Patentee* & $\begin{array}{l}-.196 \\
(.186)\end{array}$ & -.065 & $\begin{array}{l}-.194 \\
(.185)\end{array}$ & -.064 \\
\hline $\begin{array}{l}\text { JP Inventor - SP } \\
\text { Inventor }\end{array}$ & $\begin{array}{l}-.236 \\
(.163)\end{array}$ & -.081 & & \\
\hline $\begin{array}{l}\text { JP small entity - SP } \\
\text { small entity }\end{array}$ & & & $\begin{array}{l}.042 \\
(.137)\end{array}$ & .014 \\
\hline constant & $\begin{array}{l}-.129 \\
(.140)\end{array}$ & & $\begin{array}{l}-.133 \\
(.140)\end{array}$ & \\
\hline $\begin{array}{l}\text { Number of obs } \\
\text { obs. P } \\
\text { pred. P }\end{array}$ & 584 & $\begin{array}{l}.318 \\
.291\end{array}$ & 584 & $\begin{array}{l}0.318 \\
.291\end{array}$ \\
\hline $\begin{array}{l}\text { Log likelihood } \\
\left(^{*}\right) d F / d x \text { is for discrete }\end{array}$ & $\begin{array}{l}-332.99652 \\
\text { inge of dumm }\end{array}$ & iable & $\begin{array}{l}-333.16864 \\
\text { n } 0 \text { to } 1\end{array}$ & \\
\hline
\end{tabular}




\begin{tabular}{|c|c|c|c|c|c|c|c|c|c|c|}
\hline \multicolumn{11}{|c|}{ Appendix Table: Data for calculating interfering rates } \\
\hline & Chemicals & Computers & Drugs & Electrical & Mechanical & Other & All & Biotech & $\begin{array}{l}\text { Med } \\
\text { Equip }\end{array}$ & $\begin{array}{l}\text { Drugs- } \\
\text { other }\end{array}$ \\
\hline \multicolumn{11}{|c|}{ Number of Interfered Applications from cohort years in Interferences Declared 1988 - 1993} \\
\hline $76-78$ & 4 & & 6 & 1 & 6 & 5 & 22 & & & 6 \\
\hline $79-81$ & 21 & 1 & 15 & 1 & 9 & 6 & 53 & 7 & 2 & 6 \\
\hline $82-84$ & 87 & 12 & 84 & 24 & 26 & 27 & 260 & 25 & 17 & 42 \\
\hline $85-87$ & 163 & 28 & 150 & 46 & 68 & 68 & 523 & 51 & 25 & 74 \\
\hline $88-90$ & 116 & 23 & 93 & 55 & 98 & 74 & 459 & 26 & 18 & 49 \\
\hline $91-93$ & 11 & 4 & 7 & 7 & 12 & 8 & 49 & & 5 & 2 \\
\hline \multicolumn{11}{|c|}{ Total number of Applications in Cohort Years that mature to a patent } \\
\hline $76-78$ & 44,990 & 12,867 & 11,202 & 31,355 & 49,550 & 47,439 & 197,403 & 1,096 & 3,302 & 6,804 \\
\hline $79-81$ & 44,210 & 15,447 & 12,650 & 32,357 & 46,924 & 44,557 & 196,145 & 1,534 & 3,858 & 7,258 \\
\hline $82-84$ & 42,314 & 17,697 & 14,021 & 32,762 & 44,536 & 42,349 & 193,679 & 1,963 & 4,410 & 7,648 \\
\hline $85-87$ & 45,856 & 22,305 & 18,818 & 38,920 & 52,448 & 49,693 & 228,040 & 2,499 & 6,402 & 9,917 \\
\hline $88-90$ & 55,852 & 32,407 & 24,689 & 50,326 & 62,812 & 59,529 & 285,616 & 3,198 & 8,754 & 12,737 \\
\hline $91-93$ & 58,172 & 41,973 & 30,779 & 55,779 & 64,337 & 61,198 & 312,241 & 5,004 & 11,452 & 14,323 \\
\hline \multicolumn{11}{|l|}{$\begin{array}{l}\text { rate of } \\
\text { interference } \\
\text { for sample }\end{array}$} \\
\hline per thousand & 4.22 & 1.40 & 9.84 & 1.60 & 1.97 & 1.81 & 2.89 & 22.92 & 5.39 & 9.32 \\
\hline $\begin{array}{l}\text { estimated } \\
\text { rate of } \\
\text { interference; } \\
\text { inflating } \\
\text { from } 46.1 \% \\
\text { sample }\end{array}$ & 9.15 & 3.04 & 21.34 & 3.47 & 4.27 & 3.93 & 6.27 & 49.71 & 11.68 & 20.23 \\
\hline
\end{tabular}

